\title{
POSITIVE ACCOUNTING THEORY (PAT): TELAAH LITERATUR DARI BERBAGAI PERSPEKTIF
}

\author{
Marlina Magdalena
}

Jurusan Akuntansi Program Studi Akuntansi

Politeknik Negeri Malang

Email:magdanana14@gmail.com

\begin{abstract}
Watts and Zimmermen are the represents the first developer of Positive Accounting Theory (PAT) which has provided a new direction in the development of accounting research in the mid-1960s. In the 1940s and early 1960s research in accounting is dominated by normative research that more emphasis on what should happen in the world of accounting. This differs from the PAT that put more emphasis on how accounting theory can explain and predict the phenomena occurring in the real world of accounting.

The friction from normative to positive approaches that occur in accounting research, several things happen because of, among others: (1) the inability of the normative approach in testing the theory empirically, (2) normative approach is more focused on investors, and (3) normative approach does not allow the allocation of capital in the stock market. Now days a lot of positive research is dominated by the accounting practices related to decision making for investors. Many researchers who have PAT provides empirical evidence about accounting practices, such as Ball and Brown, Healy, Jensen and Meckling and many other researchers.

In addition to providing new insights in accounting research, PAT proposed by Watts and Zimmermen also getting some criticism from researchers in the environment of accounting, such as Sterling, Christenson and some other researchers associated with the methods, methodologies and the development of the PAT.
\end{abstract}

Keyword: Positive accounting theory, some critical to positive accounting theory

\begin{abstract}
Abstrak:
Watts dan Zimmermen merupakan pencetus pertama Teori Akuntansi Positif (PAT) yang telah memberikan arah baru dalam pengembangan penelitian akuntansi pada pertengahan tahun 1960-an. Pada tahun 1940-an dan awal 1960-an penelitian akuntansi didominasi oleh penelitian normatif yang menekankan pada kejadian yang seharusnya pada dunia akuntansi. Yang berbeda dari PAT ini adalah lebih menekankan bagaimana teori akuntansi dapat menjelaskan dan memprediksi fenomena berdasarkan kejadian nyata di dunia akuntansi.

Perubahan dari pendekatan normatif ke pendekatan positif dalam penelitian akuntansi dikarenakan beberapa hal sebagai berikut: (1) ketidakmampuan dari pendekatan normatif dalam menguji teori secara empiris;(2) pendekatan normatif lebih berfokus pada investor, dan (3) pendekatan normatif tidak memungkinkan alokasi modal dalam pasar saham. Sekarang ini penelitian positif didominasi oleh praktik akuntansi yang dihubungkan dengan pengambilan keputusan oleh investor. Banyak sekali peneliti yang menggunakan PAT untuk membuktikan secara empiris mengenai praktik akuntansi seperti Ball dan Brown, Heally, Jensen dan Mckling dan masih banyak lagi.
\end{abstract}


Hal ini memberikan tambahan wawasan baru dalam penelitian akuntansi, PAT yang diusulkan oleh Watts dan Zimmermen juga mendapatkan sejumlah kritik dari peneliti di bidang akuntansi seperti Sterling, Cristenson dan sejumlah peneliti yang lain yang berkaitan dengan metodologi dan perkembangan dari PAT sendiri.

Kata Kunci: Teori Akuntansi Positif, Kritik terhadap Teori Akuntansi Positif 


\section{PENDAHULUAN}

Teori sering kali dijadikan dasar sebuah tindakan atau praktik.Gaffikin (2008:4) mengemukakan bahwa pengembangan sebuah teori didesain untuk mendapatkan sebuah pengertian dan kemudian teori tersebut dapat menjelaskan sebuah fenomena yang terjadi.Manullang (2005) menambahkan bahwa berbeda dengan ilmu pasti (natural science) di mana teori dikembangkan dari hasil observasi empiris, ilmu akuntansi cenderung dikembangkan atas dasar pertimbangan nilai (value judgement) yang dipengaruhi oleh lingkungan di mana akuntansi diaplikasikan.

Teori yang dapat dinyatakan dalam bentuk kata dan simbol, yang disebut dalam filsafat pengetahuan sebagai semiology. Semiology terdiri dari 3 unsur teori yaitu (a) Sintektik: berhubungan dengan tata bahasa atau hubungan antar simbol dengan simbol, (b) Semantik: menunjukkan makna atau hubungan antara kata, tanda atau simbol dengan objek yang ada di dunia nyata. (c) Pragmatis: menunjukkan pengaruh kata-kata atau simbol terhadap seseorang. Dalam kaitannya dengan akuntansi, teori akuntansi berkaitan erat dengan aspek pragmatis yaitu bagaimana konsep dan praktik akuntansi mempengaruhi perilaku seseorang (Manullang, 2005).

Teori akuntansi berkembang sejak awal abad ke-20 dan dapat dikatakan bahwa perkembangan teori akuntansi diawali oleh tulisan Patton and Littleton (1940) yang berjudul An Introduction to Corporate Accounting Standards. Tulisan ini membawa dampak besar dalam sejarah penyusunan teori akuntansi yang pada saat itu difokuskan pada penentuan basic postulate dan pengembangan rerangka konseptual (Astika, 2009)

Istilah teori akuntansi sendiri sering dikaitkan untuk menunjukkan konsep-konsep akuntansi yang relevan dengan praktik akuntansi yang ada.Pengembangan terhadap teori akuntansi telah dilakukan, namun tidak satupun dari teori-teori tersebut yang mampu secara tuntas dan menyeluruh tentang apa yang dinamakan teori akuntansi. Belkaoui (2004:56) mengatakan bahwa sampai saat ini tidak ada teori akuntansi yang bersifat komprehensif.

Selama tahun 1950-an dan awal 1960-an riset akuntansi lebih banyak dilakukan terhadap rekomendasi kebijakan dan apa yang seharusnya dilakukan, bukan pada analisa dan penjelasan mengenai praktik akuntansi yang ada. Teori normatif ini banyak 
mendapatkan kritikan karena dasar pemikiran yang digunakan untuk menganalisis teori ini dianggap terlalu sederhana dan tidak memberikan dasar teoritik yang kuat.

Teori normatif mulai dipertanyakan relevansinya pada tahun 1960-an dengan munculnya efficiency market hypotheses (EMH) yang memberikan pengaruh besar terhadap dunia riset akuntansi. Watts dan Zimmermen memberikan alternatif pendekatan bagi penelitian di bidang akuntansi yang dikenal dengan positive accounting theory (PAT) dengan mempublikasikan artikel penelitiannya Toward a Positive Accounting Theory of Accounting Standard dalam The Accounting Review pada tahun 1978.

Kajian ini akan membahas mengenai PAT dilihat dari beberapa perspektif, antara lain sejarah munculnya PAT, pergeseran pendekatan dari normatif ke positif, kemudian perkembangan PAT serta riset mengenai PAT dan juga kritik terhadap PAT.

\section{THE RISE POSITIVE ACCOUNTING THEORY}

Watts dalam Deegan (2014:206) mengatakan bahwa sejarah munculnya PAT disebabkan oleh perubahan aliran bisnis di AS pada tahun 1950-an dan 1960-an. Pergeseran paradigma dihubungkan dengan perubahan dalam aliran bisnis AS di akhir tahun 50an dan awal tahun 60an. Laporan tentang pendidikan bisnis ditetapkan oleh Yayasan Ford dan Carnegie Corporation of New York adalah katalis bagi perubahan tersebut ... Membuat dan menguji hipotesa dipandang sebagai penting bagi penelitian yang bagus.

Selain itu munculnya PAT juga disebabkan oleh adanya kemajuan fasilitas dalam menghitung sehingga memudahkan proses analisa data dalam jumlah besar yang digunakan dalam penelitian PAT seperti yang dinyatakan oleh dinyatakan Watts dan Zimmerman dalam Deegan (2014:206) bahwa komputer dan basis data mesin yang dapat dibaca (CRSP dan Compustat) menjadi tersedia di tahun 60an. Dan, sebagian dalam merespon terhadap biaya yang turun dari pekerjaan empiris, keuangan dan teori positif ekonomi menjadi tersedia bagi pemakaian peneliti akuntansi. Ini mengarah pada perkembangan penelitian akuntansi positif dan pada peneliti yang terlatih dalam metodologi teori positif.

Adanya kritik terhadap teori akuntansi normatif juga menjadi alasan munculnya PAT. Jensen dan Meckling (1976) menyatakan bahwa "teori" dalam akuntansi tidak lebih dari sekedar sebuah proposisi normatif. Teori akuntansi hampir sepenuhnya 
berisikan tentang apa yang seharusnya dilakukan oleh para akuntan. Bahkan Jensen menambahkan bahwa riset akuntansi tidak ilmiah dikarenakan fokus riset akuntansi sebatas pada definisional dan terlampau normatif. Dari beberapa alasan yang telah dikemukakan di atas merupakan awal mula munculnya PAT dalam dunia akuntansi.

\section{THE DEFINITION OFPOSITIVE ACCOUNTING THEORY}

Dalam ilmu ekonomi, Lo (2003) mengatakan bahwa konsep positif digunakan untuk membedakannya dari argumen normatif.Istilah teori positif dipopulerkan pertama kali oleh Friedman pada tahun 1953.Watts dan Zimmerman menggunakan istilah teori positif karena umum digunakan dalam ilmu ekonomi. Mereka berpendapat proposisi positif berbeda dengan proposisi normatif.Proposisi positif berhubungan dengan bagaimana dunia bekerja, sedangkan proposisi normatif berhubungan dengan ketentuanketentuan.

Positive theory merupakan teori yang berusaha untuk menjelaskan dan memprediksikan fenomena tertentu. Seperti yang dinyatakan Watts dan Zimmerman dalam Scott (2015:284) tentang PAT yakni Teori akuntansi positif (PAT) berkaitan dengan prediksi tindakan seperti pilihan kebijakan akuntansi oleh perusahaan dan bagaimana perusahaan akan merespon standar akuntansi baru yang sedang diajukan.

Dari uraian di atas, dapat dikemukakan bahwa PAT menekankan apakah teori akuntansi yang dikemukakan dalam literatur akuntansi dapat menjelaskan praktik-praktik akuntansi yang dilakukan dan meramalkan sebab dari fenomena yang sedang terjadi sekarang ini serta pengaruhnya di masa mendatang.

\section{THE PERSPECTIVE FRICTION FROMNORMATIVE ACCOUNTING TO POSITIVE}

Dalam mempelajari teori akuntansi, terkadang kita dibingungkan antara teori akuntansi normatif dengan teori akuntansi positif.Watts dan Zimmermen (1986:98) menjelaskan pengertian teori akuntansi normatif sebagai berikut:

...accounting theoriests became much more concerned with prescribing how firm should report ......; the became more noramtive-concerned with what should be done. Very little concerned was exhibited for the empirical validity of the hypotheses on which the normative prescriptions rested.

Jika dilihat dari pengertian di atas, maka teori normatif berusaha menjelaskan apa 
yang seharusnya dilakukan oleh akuntan dalam proses penyajian informasi keuangan kepada para pemakai dan bukan menjelaskan tentang apakah informasi keuangan itu dan mengapa hal itu terjadi. Hal ini sangat berbeda dengan tujuan dari PAT yang berusaha untuk menguraikan dan menjelaskan apa dan bagaimana informasi keuangan itu disajikan dan dikomunikasikan kepada para pemakai informasi akuntansi.

Deegan (2014:202) dengan bahasa yang lebih sederhana mengemukakan bahwa PAT merupakan pendekatan yang digunakan untuk menganalisis "apa yang terjadi" yang berlawanan dengan pendekatan normatif yang digunakan untuk menganalisis "apa yang seharusnya terjadi”".

Seperti telah disampaikan pada pendahuluan bahwa pendekatan normatif dalam teori akuntansi mendapatkan perhatian yang besar pada tahun 1940-an sampai pertengahan 1960-an dengan dikeluarkannya monograph teori akuntansi no.3 yang ditulis oleh Paton dan Littleton yang berjudul "An introduction to Corporate Accounting Standards" pada tahun 1940. Namun pada pertengahan tahun 1960-an, teori akuntansi normatif mulai ditanyakan relevansinya dengan munculnya EMH yang berpengaruh besar terhadap penelitian akuntansi ke depannya. Sejak saat itu mulai muncul gagasan yang berlawanan dengan teori normatif yang menyatakan bahwa pasar modal tidak menyesatkan secara sistematis oleh teknik dan metode akuntansi tertentu (Watts dan Zimmermen, 1990)

Watts dan Zimmermen (1986:104) menyatakan beberapa alasan mengapa terjadi pergeseran dari teori normatif menuju PAT:

a. Ketidakmampuan pendekatan normatif dalam menguji teori secara empiris.

b. Pendekatan normatif lebih banyak berfokus pada kemakmuran investor secara individual daripada kemakmuran masyarakat luas.

c. Pendekatan normatif tidak mendorong atau memungkinkan terjadinya alokasi sumber daya ekonomi secara optimal di pasar modal.

Seperti telah dijelaskan pada pendahuluan di atas, sejak adanya konsep EMH yang menyatakan bahwa harga saham akan berubah dengan cepat apabila terdapat informasi baru, hal ini membawa dampak terhadap perkembangan teori akuntansi. Konsep ini membawa dampak terjadinya pergesaran dari teori akuntansi normatif menuju PAT. 


\section{THE DEVELOPMENT OF POSITIVE ACCOUNTING THEORY}

Perkembangan PAT menurut Godfrey (1994:57) dapat dibagi dalam dua tahapan yaitu:

a) Tahap pertama, tahapan ini berisi tentang penelitian mengenai hubungan antara pengumuman laba dengan reaksi harga saham.

Penelitian-penelitian pada tahap ini juga menunjukkan bahwa laporan akuntansi yang disiapkan sesuai dengan metode biaya historis menyediakan informasi yang digunakan dalam penilaian saham.Effisiensi Markets Hypothesis (EMH) dan Capital Aset Pricing Models (CAPM) juga termasuk dalam tahapan ini.Konsep EMH pertama kali dikemukakan oleh Fama pada tahun 1965.EMH merupakan konsep di mana pasar modal dikatakan efisien jika harga saham benar-benar mencerminkan semua informasi yang relevan. Pada tahun 1970, Fama membagi tiga tingkatan dalam konsep EMH yaitu weak form efficiency (diasumsikan bahwa harga saham saat ini mencerminkan informasi di masa lalu), semi strong form efficiency (diasumsikan bahwa harga saham saat ini mencerimankan informasi masa lalu dan informasi yang dipublikasikan kepada publik), dan strong form efficiency ( diasumsikan bahwa harga saham saat ini mencerminkan semua informasi baik yang dipublikasikan atau tidak).

b) Tahap kedua, penelitian yang termasuk dalam tahapan ini lebih menekankan pada literatur yang menjelaskan dan memprediksi praktik-praktik lintas perusahaan.

Teori yang dikembangkan dari penelitian dalam tahap ini berhubungan erat dengan tujuan perusahan untuk memaksimalkan kemakmuran pemegang saham. Penelitian yang terkenal dalam tahapan ini adalah mengenai agency cost yang dilakukan oleh Jensen dan Meckling pada tahun 1976. Penelitian yang dilakukan oleh Jensen dan Meckling menemukan bahwa manajer (agen) yang diangkat oleh pemegang saham (principal) sering sekali mengalami konflik kepentingan dalam kenyataannya. Konfik kepentingan ini disebut agency problem yang akan menyebabkan agency cost.

Kabir (2002) mengemukakan bahwa PAT dalam empat dekade terakhir ini berkembang menjadi sebuah ilmu sains yang dapat digunakan untuk menjelaskan pilihan metode yang akan digunakan oleh manajer maupun konstituen lain dari laporan keuangan. 
Deegan (2014:205) mengemukakan bahwa perkembangan PAT tidak lepas dari makalah dari Ray Ball dan Philip Brown, publikasi Ball dan Brown pada tahun 1968 dalam Journal of Accounting Research menyebabkan ketertarikan pada penelitian positif yang tersebar luas pada penelitian pasar modal yang terkait dengan akuntansi. Selain itu perkembangan PAT juga didukung oleh karya teoritisi Fama yang terkait dengan perkembangan EMH.

Menurut Watts dan Zimmermen (1986:65) PAT mempunyai dua elemen utama yaitu asumsi dan hipotesis. Asumsi merupakan titik awal di mana seorang peneliti mulai dari penelitian. Peneliti menggunakan asumsi untuk mengatur, menganalisis, dan memahami fenomena empiris yang berkaitan dengan fokus penelitian seperti penggunaan metode LIFO dan FIFO untuk meminimalkan kewajiban pajak. Dari asumsi ini, maka peneliti dapat menggunakan hipotesis untuk diuji empiris. Asumsi yang digunakan dalam PAT adalah kesepakatan bahwa pasar modal adalah efisien (efficient capital markets), behavioral opportunistic dan juga informasi akuntansi adalah komoditi ekonomi dan komoditi politik serta setiap individu bertindak atas kepentingan diri sendiri secara rasional.

Watts dan Zimmermen dalam makalahnya yang berjudul "Positive Accounting Theory: A Ten Years Perspective" (1990) mengemukakan tiga hipotesis dari PAT yaitu:

1. The bonus plan hypotheses. Hipotesis ini mengemukakan bahwa manajer akan memilih prosedur akuntansi yang akan menggeser pendapatan di masa mendatang ke periode sekarang dengan tujuan untuk mendapatkan bonus.

2. Hipotesis perjanjian hutang. Hipotesis ini mengemukakan bahwa bagi perusahaan yang akan melanggar perjanjian hutang, maka manajer akan memiliki kemungkinan akan memilih prosedur akuntansi yang menggeser pendapatan periode mendatang ke periode sekarang sehingga meningkatkan laba bersih dan akhirnya menghindari kesalahan teknis.

3. Hipotesis biaya politik.Hipotesis ini mengemukakan bahwa perusahaan yang memiliki profitabilitas tinggi akan cenderung menggeser pendapatannya dari periode ini ke periode mendatang untuk menghindari adanya biaya politis.

Ketiga hipotesis ini membentuk komponen yang penting dari PAT dan akan mengarah pada prediksi yang dapat diuji secara empiris. 


\section{EMPIRICAL RESEARCH FROMPOSITIVE ACCOUNTING THEORY}

Sejak kemunculannya pada tahun 1970-an, Riyono (1996) mengemukakan bahwa PAT telah melahirkan beberapa penelitian penting untuk mengeksplorasi praktek akuntansi dan perilaku pihak terkait dalam suatu organisasi secara empiris.

Penelitian empiris mengenai PAT pertama kali dilakukan oleh Ball dan Brown pada tahun 1968 serta Beaver pada tahun yang sama telah berhasil memberikan bukti empiris bahwa pengumuman laba berpengaruh terhadap harga saham dan juga volume perdagangan saham suatu perusahaan. Kedua karya inilah yang menjadi acuan bagi penelitian-penelitian PAT pada masa mendatang.

Scott (2015:290-293) mengemukakan beberapa penelitian dari PAT yaitu antara lain:

1. Penelitian Lev (1979), Lev tidak membuat rekomendasi apapun tentang bagaimana perusahaan dan investor harus bereaksi terhadap eksposure draft dari SFAS 19. Lev hanya menekankan pada bagaimana investor bereaksi pada prospek perusahaan minyak dan gas yang menggunakan metode full-cost untuk berpindah pada metode succesfull-effort. Jadi studi Lev membantu kita memahami mengapa perusahaan yang berbeda memilih kebijakan akuntansi yang berbeda dan mengapa sejumlah manajer keberatan terhadap perubahan dalam kebijakan tersebut serta mengapa investor bereaksi pada dampak potensial dari perubahan kebijakan akuntansi atas income bersih.

2. Penelitian Healy (1985) yang menguji tentang hypotheses bonus plan. Healy menemukan bukti bahwa manajer perusahaan yang mempunyai rencana bonus akan mengadopsi secara sistematis kebijakan akrual untuk memaksimalkan bonusnya.

3. Penelitian Sweeney (1994) mengenai hypotheses debt covenant. Sweeney menemukan bahwa perjanjian yang paling sering dilanggar berhubungan dengan pemeliharaan modal kerja dan ekuitas pemegang saham, sedangkan rasio hutang terhadap ekuitas dan rasio cakupan bunga tidak terlalu sering dilanggar.

4. Penelitian Jones (1991)meneliti tentang hypotheses political cost. Jones menemukan bahwa perusahaanmenurunkan income bersih yang dilaporkannya selama investigasi keringanan/pembebasan impor. Ini terkait dengan aspek biaya politik. 


\section{SOME CRITIC TOPOSITIVE ACCOUNTING THEORY}

Gagasan PAT yang dikemukakan oleh Watts dan Zimmermen tidak hanya kontroversial tetapi juga menimbulkan kritik dan sanggahan dari berbagai pihak. Ekowati (2006) mengemukakan bahwa terdapat beberapa kritikan yang ditujukan bagi PAT yang dipandang dari berbagai perspektif yaitu:

a. Perspektif Metode Riset

Ball dan Foster pada tahun 1982; Holthausen dan Leftwich pada tahun 1983 dan McKee et.al pada tahun 1984 dalam Ekowati (2006) mengemukakan bahwa metode riset yang dilakukan oleh Watts dan Zimmermen lemah dalam reduksi kekuatan tes. Tes pada PAT kurang kuat dikarenakan masalah-masalah yang berkaitan dengan spesifikasi model, masalah-masalah yang menspesifikasikan variabel sebelah kiri dan kanan, dan variabelvariabel yang dihilangkan.

Sedangkan Lev dan Ohlson pada tahun 1982 dalam Ekowati (2006) memandang PAT tidak dapat digunakan untuk model multipersonal, multiperiod equilibria, juga terdapat kesenjangan antara strategic consedirations dan pendekatan game theory yang dijadikan basis pengembangan teori formal.

Kemudian Houlthausen dan Leftwich pada tahun 1983 melihat terdapat dikotomi problematik dari variabel dependen yang mempresentasikan persetujuan atau ketidaksetujuan dalam penentuan standar akuntansi. McKee, Bell dan Boatsman pada tahun 1984 juga memandang bahwa terdapat bias identifikasi statistik dalam studi Watts dan Zimmermen.

b. Perspektif Metodologi Riset

Watts dan Zimmermen mengemukakan bahwa PAT merupakan teori yang mengandung nilai. Cristenson (1983) mengkritik pendapat Watts yang menyatakan bahwa "Teori positif dalam penetapan standart akuntansi adalah penting untuk memastikan bahwa preskripsi yang diberikan oleh teori normatif memang benar dan layak untuk diterapkan”. (Watts dan Zimmermen, 1978).

Cristenson (1983) juga menambahkan bahwa pertanyaan-pertanyaan riset positif hanya terpaku pada pendekatan sosiologi bukan pada teori akuntansi, hal ini dikarenakan deskripsi dan prediksi hanya mengenai perilaku akuntan dan manajer, bukan pada perilaku entitas-entitas akuntansi. 


\section{c. Perspektif Lingkup di luar Riset}

Sterling mengganggap PAT tidak memenuhi syarat sebagai ilmu yang utuh tetapi hanya dianggap sebagai “cottage industri”. Dari segi praktik akuntansi, PAT bertujuan untuk menjelaskan dan memprediksi. Konsep ini mendefinisikan fenomena akuntansi sebagai konstruksi matematik yang digunakan untuk mempresentasikan bentuk-bentuk informasi akuntansi. Bagi Sterling, konstruk ini dianggap hanya menggambarkan katakata dan angka-angka yang dapat dilihat dalam bentuk riil dan kejadian nyata.

Watts dan Zimmermen mengatakan bahwa akuntan akan berusaha memaksimalkan kepentingan individu. Boland dan Gordon mengkritik bahwa dalam teori ekonomi sendiri, maksimalisasi kepentingan individu tidak dapat sepenuhnya dilakukan karena juga harus mempertimbangkan kepentingan bersama.

Selain itu, kritik terhadap PAT dari Watts dan Zimmermen juga datang dari Milne (2001) yang mengemukakan penelitian akuntansi positif telah sedikit menawarkan pemahaman kita tentang pengungkapan perilaku sosial perusahaan, tapi untuk alasan yang berbeda.Hal itu menunjukkan teori akuntansi positif gagal untuk menawarkan bukti substantif apa pun untuk mendukung pandangan bahwa perusahaan menggunakan laporan tahunan pengungkapan sosial dalam mengejar kekayaan kepentingan mereka sendiri. Bahkan, di hampir semua kasus penelitian empiris pengaturan untuk menguji teori akuntansi positif sebagai dasar untuk pengungkapan sosial perilaku telah gagal untuk mengikuti argumen dari Watts dan Zimmerman.

Whittington (1987: 329) dalam Lo (2003) mengkritik pernyataan bahwa teori akuntansi positif adalah bebas dari penilaian subyektif dan bersifat ilmiah sedangkan teori normatif mempunyai penilaian subyektif yang tinggi dan tidak ilmiah, adalah tidak dapat diterima dengan dua keberatan sebagai berikut:

1. Teori akuntansi positif tidak bebas dari penilaian atau implikasi preskriptif.

2. Anggapan bahwa semua teori yang tidak positif adalah normatif dalam arti mengarah pada preskripsi-preskripsi, adalah tidak benar.

Deegan (2014: 236-239) menuliskan beberapa kritik terhadap PAT antara lain:

a) PAT tidak memberikan resep dan oleh karena itu tidak menyediakan sarana memperbaiki praktik akuntansi. Sterling menambahkan bahwa PAT 
tidak dapat memberikan beberapa jawaban karena ia membatasi dirinya sendiri pada pertanyaan deskriptif.

b) Kritik kedua PAT adalah bahwa itu tidak bebas nilai, seperti yang ditegaskan. Jika kita melihat beragam penelitian yang memakai PAT, kita akan melihat tidak adanya rumusan (yaitu, tidak ada pedoman seperti apa yang yang harus dilakukan).

c) Kritik ketiga PAT terkait dengan asumsi dasar bahwa semua tindakan dikendalikan oleh keinginan untuk memaksimalkan kesejahteraan seseorang. Bagi banyak peneliti asumsi seperti itu menunjukkan perspektif yang terlalu negatif dari manusia

d) Kritik lain atas PAT adalah bahwa karena permulaan umumnya di tahun 70an masalah yang dibahas tidak menunjukkan perkembangan besar. Review literatur PAT sekarang menunjukkan bahwa hipotesa ini terus diuji pada lingkungan yang berbeda dan dalam hubungan dengan masalah kebijakan akuntansi yang berbeda bahkan setelah dua puluh tahun berlalu sejak Watts dan Zimmerman pada tahun 1978.

e) Kritik selanjutnya adalah bahwa PAT secara ilmiah cacat. Diperdebatkan bahwa saat hipotesa menghasilkan pengejaran bagi PAT seringkali hipotesis yang diajukan tidak didukung, maka secarailmiah PAT harusnya ditolak.

Sejumlah kritik yang diberikan oleh beberapa peneliti di bidang akuntansi tersebut tidak menyurutkan besarnya perhatian terhadap riset PAT ini, sampai saat ini masih banyak riset-riset akuntansi yang menggunakan pendekatan PAT. 


\section{SIMPULAN DAN SARAN}

Teori akuntansi yang ada sekarang ini tidak terlepas dari peran Watts dan Zimmermen yang memperkenalkan PAT ke dalam penelitian akuntansi pada tahun 1978 melalui makalah mereka yang diterbitkan oleh The Accounting Review yang berjudul Toward a Positive Accounting Theory of accounting Standard yang telah menggeser paradigma penelitian akuntansi dari normatif menjadi positif. Kemudian pada tahun 1990 mereka mengemukakan Hypotheses of Positive Accounting Theory yang di dalamnya terdapat rencana bonus, pelanggaran perjanjian hutang dan biaya politis yang menjadi acuan utama dalam penelitian akuntansi sekarang ini. Tidak hanya dukungan yang diberikan dalam perkembangan PAT ini, banyak juga kritikan yang datang pada Watts dan Zimmermen seperti dari Sterling, Ball dan Foster, Lev dan Ohlson, Cristenson dan banyak lagi yang lainnya.

Namun dengan adanya kritik dan juga dukungan yang diberikan kepada PAT, PAT sendiri telah memberikan warna tersendiri bagi dunia akuntansi khususnya pada pengembangan teori akuntansi. 


\section{DAFTAR PUSTAKA}

Astika, I.B. Putra. 2009. Hubungan Keagenan Dan Hukum Besi Dalam Manajemen Laba. Desertasi Program Magister Sain dan Doktor FE UGM.

Belkaoui Ahmad. 2004. Accounting Theory, 5 ${ }^{\text {rd }}$, Ed-Orlando: Harcourt Brace, Jovanovich

Budiarto, Arief., dan Murtanto. 1999. Teori Akuntansi: Dari Pendekatan Normatif Ke Positif. Jurnal Bisnis Dan Akuntansi. Vol 1. No.3: 163-182.

Christenson, Charles. 1983. The Metodologi of Positive Accounting. JAR. No. 1

Deegan, Craig. 2014. Financial Accounting Theory. McGraw-Hill, Australia

Ekowati, Wiwik Hidajah. 2006. Kritik Terhadap Positive Accounting Theory (PAT) Dan Menuju PAT Yang Lebih Bernilai, TEMA, Volume 7, Nomor 2: 141-155.

Gaffikin, M. 2008. Accounting Theory-research, Regulation and Accounting Practice.Pearson Education. Australia

Godfrey, J, Allan Hohgson, Scott Holmes dan Vernon Kam. 1994. Accounting Theory. Second Edition. Brisbane: John Wiley dan Sons

Healy, P.M. The Effect of Bonus Schemes on Accounting Decisions.Journal Accounting and Economic (April, 1985), pp. 85-107

Jensen, M.C dan W. H Meckling. 1976. Theory of The Firm: Managerial Behavior. Agency Costs and Ownership Structure.Journal of Accounting Economic.(October, 1976), pp. 305-360.

Jones, J. 1991. Earning Management During Import Relief Investigations. Journal of Accounting Research. pp. 193-228

Lev, B. 1979. The Impact of Accounting Regulation on the Stock Market; The Case of Oil and Gas Companies. The Accounting Review. (July, 1976), pp.485-503

Lo, Eko Widodo. 2003. Filsafat Ilmu Sebagai Dasar Dan Arah Pengembangan Akuntansi Menuju Ke Arah Peningkatan Kualitas Profesi Akuntan. Jurnal Akuntansi dan Manajemen. Vol 14. No 1.

Manullang, Laurence (2005). Teori Akuntansi dengan Pendekatan Peristiwa (Event Approach) (Kasus Pengungkapan Korupsi).Pidato Pengukuhan Guru Besar Dalam Ilmu Akuntansi tidak diterbitkan. Jakarta: STIE IBEK.

Muqodim.2005 Teori Akuntansi. Yogyakarta: EKONISIA

Riduwan, Akhmad. 2007. Teori Akuntansi: Dari Normatif Ke Positif, Isu Bebas Nilai, Hingga Mitos Dan Wacana Redifinisi Akuntansi. TEMA. Volume 8, No 1: 16-25.

Riyono, Bogat Agus. 1996. The Rise Of Positive Accounting Theory, Lintasan Ekonomi, Edisi April: 985-989.

Scott, William R. 2015. Financial Accounting Theory, 7th, Pearson Prentice-Hall, Canada 
Suwardjono. 1989. Teori Akuntansi: Perekayasaan Akuntansi Keuangan.BPFE. Yogyakarta

Sweeney, A.P. 1994. Debt Covenant Violations and Managers Accounting Responses.Journal of Accounting and Economic, May, 281-308

Watts, Ross L., dan Jerold L. Zimmermen. 1978. Toward a Positive Accounting Theory of Accounting Standard. The Accounting Review.Vol 53.112-134.

Watts, Ross L., dan Jerold L. Zimmermen. 1986. Positive Accounting Theory. Englewood Cliffs, New Jersey: Prentice Hall, Inc.

Watts, Ross L., dan Jerold L. Zimmermen 1990. Positive Accounting Theory: A Ten Years Perspective. The Accounting Review.Vol 65. No 1. 131-156. 